\title{
Mengapa Kedisiplinan Mekanik Lebih Penting Dibandingkan Kepemimpinan Untuk Meningkatkan Kinerja Bengkel?
}

\author{
Ahmad Nizar Yogatama1, Hendra Leo Pratama' \\ Corresponding Author: \\ Nama Penulis: Ahmad Nizar Yogatama \\ E-mail: nizaryogatama@asia.ac.id

\begin{abstract}
:
Leadership has a more important role than discipline in employee performance, even though tolerance in leadership is the basis for the emergence of good discipline by mechanics at Bengkel Bunul Malang. This study aims to find out why discipline is more important than leadership to improve the performance of mechanics in Bunul Malang workshop. This study uses multiple linear regression analysis techniques with a population and samples, namely all mechanics in Malang Bunul workshop, amounting to 37 people. The results of this study are leadership and discipline have a significant effect on performance, but discipline has a dominant value on performance.
\end{abstract}

Keywords : Head Mechanics Leadership, Mechanics Discipline, Mechanics Performance

\begin{abstract}
Abstrak:
Kepemimpinan kepala bengkel disinyalir memiliki peran lebih penting dibandingkan kedisiplinan, padahal toleransi dalam sebuah kepemimpinan menjadi dasar munculnya kedisiplinan yang baik oleh mekanik di Bengkel Bunul Malang. Penelitian ini bertujuan untuk mengetahui mengapa kedisiplinan mekanik menjadi lebih penting untuk diperhatikan oleh pihak manajemen dan kepala bengkel untuk meningkatkan kinerja. Penelitian ini menggunakan teknik analisis regresi linier berganda dengan populasi dan sampel yakni seluruh mekanik di bengkel bunul Malang yang berjumlah 37 orang. Hasil penelitian ini adalah kedisiplinan lebih penting dibandingkan kepemimpinan yang baik terhadap kinerja dari mekanik karena toleransi yang diberikan oleh kepala bengkel kepada mekanik menjadi dasar kedisiplinan oleh mekanik sehingga mampu meningkatkan kinerja secara efektif dan efisien.
\end{abstract}

Kata kunci : Kepemimpinan Kepala Bengkel, Kedisiplinan Mekanik, Kinerja Mekanik

\section{PENDAHULUAN}

Bengkel Bunul Malang adalah salah satu diantara banyak organisasi bisnis di Kota Malang yang selalu mengutamakan kualitas dalam melakukan pelayanan terhadap setiap konsumen yang datang (Nugraha et al., 2014) dimana untuk mempertahankan kualitas pelayanan tersebut pihak manajemen harus mampu mengelola karyawan dengan baik sehingga tercipta kinerja yang sesuai dengan harapan (Bagus et al., 2015; Yogatama, 2019; Yogatama \& 
Mengapa Kedisiplinan Karyawan Lebih Penting Dibandingkan Kepemimpinan Untuk Meningkatkan Kinerja?

Mudhawati, 2020; Yogatama \& Susanti, 2020).

Seringkali kinerja karyawan selalu dikaitkan dengan kepemimpinan, yang mana hal ini tidak salah akan tetapi kepemimpinan berasal dari sisi eksternal (Bana, 2016; Hakim, 2018; Mintarsih \& Anisya, 2019). Pada berbagai penelitian dikatakan bahwa kinerja yang baik selalu berasal dari sisi internal karyawan terlebih dahulu. Hal ini karena setiap tindak tanduk dari karyawan selalu berawal dari sikap karyawan tersebut. Hal ini pula yang menjadi penting untuk diketahui pihak pengelola organisasi bisnis manapun (Anggreni, 2017; Christin \& Mukzam, 2017; Fatchurozi et al., 2019; Mataram \& Handriyono, 2018; Nidawati, 2019).

Bengkel Bunul selama ini sudah mengelola karyawan dengan baik, akan tetapi sejatinya ingin meningkatkan kinerja karyawan demi efektivitas kinerja. Untuk membangun kinerja yang efektif memang dibutuhkan berbagai upaya, salah satunya adalah penerapan kepemimpinan yang sesuai. Pada berbagai penelitian memang disebutkan bahwa kepemimpinan memang selalu memiliki peran penting dalam meningkatkan kinerja karyawan karena bertindak sebagai pengambil keputusan utama dan dianggap mampu memberikan solusi atas permasalahan yang dihadapi oleh karyawan manakala terjadi permasalahan di lapangan (Anggreni, 2017; Christin \& Mukzam, 2017; Winarto \& Laela, 2017).

Awal mula Bengkel Bunul hanya memiliki 3 karyawan, dimana terdiri dari 2 mekanik dan 1 koordinator, dan saat ini telah memiliki 37 karyawan. Ini adalah bukti bahwa kemampuan kepemimpinan yang baik, mampu menciptakan kinerja yang baik dan penerapan kepemimpinan selama ini sudah sesuai dengan kondisi sehingga Bengkel Bunul bisa berkembang sedemikian rupa dengan fakta yaitu peningkatan jumlah karyawan. Di beberapa penelitian juga dikatakan bahwa kepemimpinan memiliki peran penting terhadap kinerja dari karyawan, dimana kemampuan pengelolaan terhadap karyawan mampu meningkatkan efektivitas pekerjaan karyawan yang kemudian menciptakan kepuasan di dalam diri individu karyawan yang kemudian berujung pada peningkatan kinerja karyawan, dalam hal ini kinerja dari mekanik (Asrar-ulHaq \& Kuchinke, 2016, 2016; Pawirosumarto et al., 2017; Prabowo et al., 2018; 
Mengapa Kedisiplinan Karyawan Lebih Penting Dibandingkan Kepemimpinan Untuk Meningkatkan Kinerja? $\underline{\text { Rita et al., 2018; Schleu \& Hüffmeier, 2020; Syukri \& Heryanto, 2019; Yogatama }}$ \& Mudhawati, 2020; Yogatama \& Susanti, 2020). Hal inilah yang kemudian menjadi dasar hipotesis pertama dalam penelitian ini yaitu kepemimpinan kepala mekanik memiliki pengaruh terhadap kinerja mekanik di bengkel bunul malang.

Hal menarik adalah walaupun kepemimpinan yang diterapkan berhasil sehingga jumlah karyawan meningkat pesat, kedisiplinan menjadi permasalahan yang sering terjadi. Permasalahan kedisiplinan yang sering terjadi yaitu keterlambatan jam kerja oleh mekanik. Hal ini kemudian memicu pihak manajemen untuk melakukan restrukturisasi sehingga mengganti kepala mekanik yang dianggap kurang tegas, sehingga muncul standar kerja baru. Pola keterlambatan jam kerja dan pergantian kepala mekanik dengan standar kerja baru ini berlangsung selama beberapa waktu yang kemudian mengakibatkan kedisiplinan karyawan semakin menurun.

Tidak hanya itu, di beberapa penelitian dikatakan memang kedisiplinan memiliki kontribusi terhadap kinerja, tidak peduli jenis pekerjaannya apa (Alexandri et al., 2019; Aprizal et al., 2020; Purba et al., 2020; Ramliana et al., 2017; Rizal, 2019; Soelton, 2018; Syukri \& Heryanto, 2019). Hal inilah yang kemudian menjadi dasar hipotesis kedua dalam penelitian ini yaitu kedisiplinan mekanik diduga memiliki pengaruh terhadap kinerja mekanik di bengkel bunul malang.

Pihak manajemen tak ayal seringkali menemukan karyawan yang dengan sengaja istirahat sebelum waktunya hingga menambah jam istirahat. Bahkan, seringkali ditemukan karyawan yang menggunakan aksesoris melebihi ketentuan dan menggunakan sepatu yang tidak sesuai. Dalam praktiknya, mekanik seharusnya memiliki ketentuan khusus terkait dengan pakaian karena terkait dengan Alat Pelindung Diri (Anggreni, 2017; Indrayani et al., 2019; Kenwa et al., 2019; Mataram \& Handriyono, 2018).

Untuk meminimalisir permasalahan tersebut, seharusnya memang pihak manajemen harus melakukan komunikasi yang baik antara atasan-bawahan. Tujuannya adalah untuk membangun hubungan yang harmonis di dalam 
Mengapa Kedisiplinan Karyawan Lebih Penting Dibandingkan Kepemimpinan Untuk Meningkatkan Kinerja? sebuah organisasi bisnis sehingga tercipta suasana kerja yang baik sehingga kinerja karyawan bisa mengalami peningkatan.

Sejatinya Kepala Bengkel atau Mekanik memang harus mengerti setiap kemampuan dari karyawannya, sehingga ketika konsumen membutuhkan pelayanan segera setiap konsumen tersebut akan mendapatkan pelayanan yang sesuai dengan kemampuan dari karyawan tersebut, yang mana juga disesuaikan dengan kebutuhan dari konsumen. Disini juga berperan sebuah sikap dari karyawan serta kepala, dalam praktiknya rotasi yang dilakukan oleh pihak manajemen sering karena satu dan lain hal sehingga karyawan merasa perubahan pengelolaan yang dilakukan oleh Kepala Bengkel atau Mekanik belum benar-benar berjalan sebagaimana mestinya, dikala harus mengalami perubahan maka mau tidak mau mereka harus melakukan adaptasi kembali. Menariknya adalah kemampuan adaptasi individu karyawan satu dan lainnya berbeda, di satu sisi pihak manajemen terkesan tidak terlalu peduli dengan situasi dan kondisi ini. Penelitian ini sendiri bertujuan untuk mengetahui bagaimana peran kepemimpinan kepala mekanik terhadap kinerja mekanik selama ini, serta sejauh mana kedisiplinan mekanik berperan terhadap kinerja mekanik.

\section{METODE PENELITIAN}

Penelitian ini dilakukan pada Bengkel Bunul Malang yang berada di jalan Hamid Rusdi No. 1 Malang. Bengkel ini merupakan salah satu usaha yang bergerak dibidang jasa perbaikan kendaraan bermotor khususnya mobil. Penelitian ini sendiri ingin mengetahui hubungan antar variabel yang disebut sebagai riset kausal menggunakan dua variabel bebas dan satu variabel terikat, sehingga menggunakan analisis regresi linier berganda. Populasi dan sampel dari penelitian ini menggunakan non probability sampling, sehingga teknik yang digunakan teknik sampel jenuh yaitu seluruh karyawan Bengkel Bunul Malang yang berjumlah 37 orang.

Teknik pengumpulan data yang digunakan dalam penelitian ini adalah melalui observasi dan wawancara menggunakan kuesioner, sedangkan teknik analisis yang digunakan adalah analisis regresi linier berganda. 
Mengapa Kedisiplinan Karyawan Lebih Penting Dibandingkan Kepemimpinan Untuk Meningkatkan Kinerja?

Dalam penelitian ini, variabel kepemimpinan dimaknai sebagai bagaimana peran kepala bengkel atau mekanik terhadap para mekanik yang terdapat pada Bengkel Bunul Malang, variabel ini dinilai menggunakan beberapa indikator diantaranya adalah adil, sumber inspirasi, sebagai wakil organisasi, memberi sugesti, mendukung tujuan. Adil yang dimaksud adalah kepala mekanik mampu bersikap adil terhadap setiap mekanik yang berada dalam pengelolaannya; sumber inspirasi yaitu kepala mekanik mampu menjadi panutan bagi setiap mekanik yang berada di bawah pengelolaannya; sebagai wakil organisasi yaitu kepala mekanik mampu menjadi pihak yang mampu menerjemahkan kebijakan-kebijakan pihak pengelola dengan baik kepada mekanik; mendukung tujuan yaitu kepala mekanik mampu mendukung tujuan dari setiap mekanik yang memang sesuai dengan tujuan organisasi yakni Bengkel Bunul Malang.

Disiplin Kerja yang dimaksud disini adalah setiap mekanik bekerja sesuai dengan standar kerja yang ditentukan oleh Bengkel Bunul Malang, mulai dari jam kerja hingga bagaimana harus mendapatkan jam lembur. Variabel ini diukur menggunakan beberapa indikator diantaranya adalah taat terhadap aturan waktu, taat terhadap peraturan bengkel bunul, taat terhadap aturan perilaku dalam pekerjaan di bengkel bunul serta taat terhadap peraturan lainnya yang ditetapkan oleh bengkel bunul malang. Kinerja Karyawan atau disebut sebagai kinerja mekanik yaitu hasil pekerjaan yang dilakukan oleh mekanik selama memberikan pelayanan kepada konsumen. Variabel ini diukur menggunakan beberapa indikator diantaranya yaitu kualitas, kuantitas, ketepatan waktu serta tanggung jawab. Kualitas yang dimaksud adalah bagaimana penyelesaian masalah dan proses pemberian layanan jasa mekanik kepada konsumen di bengkel bunul malang; kuantitas yaitu jumlah pelayanan jasa yang diberikan mekanik selama jam kerja berlangsung; ketepatan waktu yaitu penyelesaian pekerjaan jasa mekanik sudah sesuai dengan standar waktu yang ditetapkan oleh bengkel bunul malang serta tanggung jawab yaitu mekanik memiliki tanggung jawab untuk menyelesaikan segala jenis layanan jasa yang diberikan kepada konsumen sesuai dengan porsinya masing-masing atau sesuai kebutuhan konsumen yang datang. 
Mengapa Kedisiplinan Karyawan Lebih Penting Dibandingkan Kepemimpinan Untuk Meningkatkan Kinerja?

\section{HASIL PENELITIAN}

Hasil olah data menunjukkan bahwa semua instrumen yang digunakan dalam penelitian telah valid dan reliabel. Untuk uji asumsi klasik, penelitian ini menggunakan uji normalitas, uji multikolinearitas serta uji heteroskedastisitas. Uji normalitas menggunakan one sample kolmogorov smirnov test dengan nilai signifikansi sebesar 0,135>0,05. Untuk uji multikolinieritas menggunakan nilai VIF (Variance Inflation Factor) sebesar $4,234<10$ untuk variabel kepemimpinan dan kedisiplinan. Terakhir, untuk uji heteroskedastisitas menggunakan uji glejser dengan nilai signifikansi sebesar 0,652 untuk variabel kepemimpinan dan 0,411 untuk variabel kedisiplinan yang semuanya memiliki nilai lebih besar dari 0,05. Setelah selesai uji asumsi klasik, data kemudian dianalisis menggunakan analisis regresi linier berganda. Hasil analisis regresi linier berganda dan uji hipotesis dapat dilihat pada Tabel 1.

Tabel 1. Hasil Analisis Regresi Linier Berganda

\begin{tabular}{|l|c|c|c|}
\hline Variabel & Koef. Regresi & t-hitung & Signifikansi \\
\hline Kepemimpinan & 0,751 & 3,209 & 0,002 \\
\hline Kedisiplinan & 0,83 & 3,159 & 0,003 \\
\hline
\end{tabular}

Sumber: data diolah peneliti, 2020.

Nilai konstanta sebesar 0,525, sehingga kinerja dari mekanik bengkel bunul malang sudah baik. Untuk uji model, penelitian ini menggunakan uji f dengan nilai sebesar 18,769 dan signifikansi sebesar 0,00. Hal ini menunjukkan bahwa model dalam penelitian ini mampu menjadi prediktor yang baik untuk memprediksi kinerja mekanik di bengkel bunul malang. Untuk nilai koefisien determinan, penelitian ini menggunakan nilai Adjusted $R$ Square dengan nilai sebesar 0,497 yang bermakna bahwa kinerja mekanik pada bengkel bunul malang mampu dijelaskan sebesar 49,7\% dalam penelitian ini berdasarkan kepemimpinan dan kedisiplinan.

\section{PEMBAHASAN}

Bengkel Bunul Malang sejatinya didirikan pada tahun 2000. Awalnya 
Mengapa Kedisiplinan Karyawan Lebih Penting Dibandingkan Kepemimpinan Untuk Meningkatkan Kinerja? Bengkel Bunul Malang hanya berfokus pada penanganan perawatan kendaraan secara berkala dan penggantian oli, akan tetapi seiring berjalannya waktu permintaan dari konsumen mengalami peningkatan sehingga saat ini bengkel bunul sudah mampu melayani segala keperluan pemilik kendaraan, baik pelayanan perbaikan jenis ringan hingga berat.

Hingga penelitian ini selesai ditulis, Bengkel Bunul sudah memiliki tiga cabang diantaranya yaitu dua bengkel khusus untuk menangani perbaikan kerusakan masing-masing terletak di Kota Malang dan sisanya bengkel khusus yang menangani perbaikan body mobil yang terletak di Kota Batu. Bengkel Bunul sejatinya berfokus penuh pada kepuasan pelanggan dengan melakukan pelayanan purna jasa dan garansi penuh terhadap jasa yang diberikan, sehingga mampu mendapatkan kepercayaan dari konsumen.

Bengkel bunul membuka pelayanan darurat selama 24 jam kepada para konsumen yang mengalami kerusakan kendaraan baik yang sedang berada dalam kota maupun luar kota, dimana dalam pelaksanaannya didukung oleh dua unit mobil khusus untuk derek maupun service yang digunakan untuk penanganan kerusakan kendaraan dijalan. Bengkel bunul sejatinya berkomitmen penuh terhadap kepuasan dan pelayanan kepada konsumen. Bengkel bunul sebenarnya memiliki visi untuk menjadi bengkel mobil terbaik di kota Malang yang mengutamakan pada kepuasan pelanggan yang juga didukung oleh peralatan lengkap dan tenaga ahli yang berkompeten dalam memberikan pelayanan jasa Bengkel kepada pelanggan, mitra usaha, pegawai, pemegang saham dan masyarakat.

Bengkel Bunul Malang sendiri memiliki 37 mekanik yang sebagian besar masih berusia muda, produktif dan berjenis kelamin laki. Hal ini karena sebagai mekanik lebih dibutuhkan tenaga fisik. Selain itu mayoritas mekanik bengkel bunul malang selama ini memiliki pendidikan yakni SMK sederajat, dimana mereka semua telah bekerja selama 2-5 tahun. Sebenarnya dari hasil penelitian ditemukan bahwa kepemimpinan yang dilaksanakan oleh kepala bengkel bunul tidak membeda-bedakan sikapnya terhadap mekanik yang dipimpinnya dalam memberi tugas sesuai dengan wewenang dan kemampuan bahkan ia juga akan 
Mengapa Kedisiplinan Karyawan Lebih Penting Dibandingkan Kepemimpinan Untuk Meningkatkan Kinerja? membantu memberikan alternatif penyelesaian jika terjadi kondisi ketidakharmonisan diantara para mekanik yang dipimpinnya, hanya saja hal ini sering terganggu dengan rotasi kepala bengkel yang sering terjadi di bengkel bunul malang, akan tetapi hingga saat ini masih bisa diatasi dengan baik.

Kepala bengkel masih bisa mengelola mekanik dengan baik dengan berbagai situasi yang dihadapi, salah satu yang dilakukan adalah dengan memberikan contoh kepada mekanik jika mekanik mengalami kendala selama proses memberikan pelayanan kepada konsumen. Dari sini, kepala bengkel mampu memberikan semangat kerja kepada mekanik sehingga mekanik memiliki inisiatif untuk bisa meningkatkan pelayanan kepada konsumen.

Terkait dengan kedisiplinan mekanik, semua mekanik sudah bekerja sesuai dengan jam kerja yang telah ditentukan, akan tetapi yang menarik adalah setiap kali tidak bisa hadir maka mekanik berkewajiban meminta izin, hal ini juga berlaku untuk permintaan cuti. Bengkel bunul sejatinya sangat baik dalam memberikan peraturan yang ditaati oleh setiap mekanik. Bentuk peraturan yang dimaksud adalah dengan memberikan standard operational procedure tentang pelayanan dan proses pemberian pelayanan terhadap konsumen. Kepemimpinan terhadap kinerja karyawan.

Memang bengkel bunul malang adalah salah satu diantara banyak organisasi bisnis di Kota Malang yang selalu mengutamakan kualitas dalam melakukan pelayanan terhadap setiap konsumen yang datang (Nugraha et al., 2014) dimana untuk mempertahankan kualitas pelayanan tersebut pihak manajemen harus mampu mengelola karyawan dengan baik sehingga tercipta kinerja yang sesuai dengan harapan. Hal ini diwujudkan melalui pembentukan standard operational procedure bagi mekanik ketika memberikan pelayanan kepada konsumen, selain itu dengan kepemimpinan kepala bengkel yang selama ini sudah baik memang memberikan acuan yang baik. Situasi seperti juga didukung oleh beberapa penelitian yang memang mengatakan bahwa pelayanan kepada konsumen akan efisien atau efektif jika diikuti dengan sistem yang baik melalui prosedur yang sesuai (Bagus et al., 2015; Yogatama, 2019; Yogatama \& Mudhawati, 2020; Yogatama \& Susanti, 2020). 
Mengapa Kedisiplinan Karyawan Lebih Penting Dibandingkan Kepemimpinan Untuk Meningkatkan Kinerja?

Seringkali kinerja karyawan selalu dikaitkan dengan kepemimpinan, yang mana hal ini tidak salah akan tetapi kepemimpinan berasal dari sisi eksternal (Bana, 2016; Hakim, 2018; Mintarsih \& Anisya, 2019). Pada berbagai penelitian dikatakan bahwa kinerja yang baik selalu berasal dari sisi internal karyawan terlebih dahulu. Hal ini karena setiap tindak tanduk dari karyawan selalu berawal dari sikap karyawan tersebut. Hal ini pula yang menjadi penting untuk diketahui pihak pengelola organisasi bisnis manapun (Anggreni, 2017; Christin \& Mukzam, 2017; Fatchurozi et al., 2019; Mataram \& Handriyono, 2018; Nidawati, 2019). Menariknya adalah Kepala bengkel masih bisa mengelola mekanik dengan baik dengan berbagai situasi yang dihadapi, salah satu yang dilakukan adalah dengan memberikan contoh kepada mekanik jika mekanik mengalami kendala selama proses memberikan pelayanan kepada konsumen. Dari sini, kepala bengkel mampu memberikan semangat kerja kepada mekanik sehingga mekanik memiliki inisiatif untuk bisa meningkatkan pelayanan kepada konsumen. Namun, beberapa hal yang kemudian bisa memicu hasil negatif adalah rotasi kepala bengkel yang sering dilakukan sehingga ketika mekanik sudah memiliki semangat harus berubah karena terjadinya rotasi kepala bengkel.

Bengkel Bunul selama ini sudah mengelola karyawan dengan baik, akan tetapi sejatinya ingin meningkatkan kinerja karyawan demi efektivitas kinerja. Untuk membangun kinerja yang efektif memang dibutuhkan berbagai upaya, salah satunya adalah penerapan kepemimpinan yang sesuai. Kepala bengkel selama ini sudah bertindak sebagaimana mestinya dengan fakta yaitu ketika melakukan pembagian pekerjaan demi memberikan pelayanan kepada konsumen, kepala bengkel sudah membagi pekerjaan dengan baik sesuai dengan kemampuan dan keterampilan mekanik. Kepemimpinan yang diterapkan oleh kepala bengkel ini sudah berada dalam jalur yang benar karena pemerataan pekerjaan akan berdampak positif bagi kinerja bengkel secara keseluruhan karena pekerjaan tidak akan terbebani pada salah satu mekanik saja, akan tetapi pekerjaan tersebut merata. Pada berbagai penelitian memang disebutkan bahwa kepemimpinan memang selalu memiliki peran penting 
Mengapa Kedisiplinan Karyawan Lebih Penting Dibandingkan Kepemimpinan Untuk Meningkatkan Kinerja? dalam meningkatkan kinerja karyawan karena bertindak sebagai pengambil keputusan utama dan dianggap mampu memberikan solusi atas permasalahan yang dihadapi oleh karyawan manakala terjadi permasalahan di lapangan (Anggreni, 2017; Christin \& Mukzam, 2017; Winarto \& Laela, 2017).

Tidak jarang kepala bengkel memang ikut membantu mekanik manakala dalam proses pemberian pelayanan mekanik mengalami kesulitan. Hal ini nanti akan berujung pada efektivitas kinerja bengkel sendiri dimana juga didukung oleh beberapa penelitian bahwa kepala bengkel wajib memiliki peran penting karena akan berdampak pada kinerja karyawan, dimana kemampuan pengelolaan kepala bengkel terhadap mekanik mampu meningkatkan efektivitas pekerjaan mekanik yang kemudian menciptakan kepuasan di dalam diri individu mekanik yang kemudian berujung pada peningkatan kinerja mekanik serta bengkel secara keseluruhan (Asrar-ul-Haq \& Kuchinke, 2016, 2016; Pawirosumarto et al., 2017; Prabowo et al., 2018; Rita et al., 2018; Schleu \& Hüffmeier, 2020; Syukri \& Heryanto, 2019; Yogatama \& Mudhawati, 2020; Yogatama \& Susanti, 2020).

Sejauh ini yang terjadi di bengkel bunul kepemimpinan kepala bengkel yang diterapkan berhasil sehingga jumlah mekanik serta konsumen meningkat pesat, kedisiplinan mekanik memang menjadi permasalahan yang sering terjadi, akan tetapi masih dalam ambang batas kewajaran. Permasalahan kedisiplinan yang sering terjadi yaitu keterlambatan jam kerja oleh mekanik. Hal ini kemudian memicu pihak manajemen untuk melakukan restrukturisasi sehingga mengganti kepala mekanik yang dianggap kurang tegas, sehingga muncul standar kerja baru. Sikap kurang tegas ini sebenarnya adalah bentuk toleransi yang diberikan oleh kepala bengkel kepada setiap mekanik yang ada di bengkel bunul, akan tetapi untuk level tertentu pihak manajemen menilai bahwa tindakan kepala bengkel ini dianggap sebagai tindakan kurang tegas sehingga diganti.

Pola keterlambatan jam kerja dan pergantian kepala mekanik dengan standar kerja baru ini berlangsung selama beberapa waktu yang kemudian justru mengakibatkan kedisiplinan karyawan semakin menurun. Padahal 
Mengapa Kedisiplinan Karyawan Lebih Penting Dibandingkan Kepemimpinan Untuk Meningkatkan Kinerja? sejatinya kedisiplinan memiliki peranan penting terhadap hasil kerja mekanik, karena dengan kedisiplinan yang dibangun mampu memberikan kinerja yang diharapkan.

Namun, terlepas dari hal tersebut kepemimpinan yang kemudian seharusnya sudah sesuai sehingga memberikan rasa nyaman dalam bekerja harus berubah karena terjadi pergantian posisi kepala bengkel menyebabkan kedisiplinan mekanik menjadi siklus yang tidak kunjung berakhir (Alexandri et al., 2019; Aprizal et al., 2020; Purba et al., 2020; Ramliana et al., 2017; Rizal, 2019; Soelton, 2018; Syukri \& Heryanto, 2019). Pihak manajemen tak ayal seringkali menemukan karyawan yang dengan sengaja istirahat sebelum waktunya hingga menambah jam istirahat.

Bahkan, seringkali ditemukan karyawan yang menggunakan aksesoris melebihi ketentuan dan menggunakan sepatu yang tidak sesuai. Dalam praktiknya, mekanik seharusnya memiliki ketentuan khusus terkait dengan pakaian karena terkait dengan Alat Pelindung Diri (Anggreni, 2017; Indrayani et al., 2019; Kenwa et al., 2019; Mataram \& Handriyono, 2018). Hal ini menunjukkan bahwa masih terdapat beberapa standard operational procedure yang kerap dilanggar dan sifatnya dianggap kurang penting.

Hal inilah yang kemudian memicu bahwa kepemimpinan kepala bengkel dianggap kurang tegas dan berujung pada pergantian kepala bengkel. Untuk meminimalisir permasalahan tersebut, seharusnya memang pihak manajemen harus melakukan komunikasi yang baik antara atasan-bawahan. Komunikasi yang dibangun tidak hanya antara pihak manajemen dan kepala bengkel, namun juga kepala bengkel terhadap mekanik. Tujuannya adalah untuk membangun hubungan yang harmonis di dalam sebuah organisasi bisnis sehingga tercipta suasana kerja yang baik sehingga kinerja mekanik bisa mengalami peningkatan.

Sejatinya Kepala Bengkel memang harus mengerti setiap kemampuan dari mekanik, sehingga ketika konsumen membutuhkan pelayanan dengan segera, setiap konsumen tersebut akan mendapatkan pelayanan yang sesuai dengan kemampuan dari karyawan tersebut, yang mana juga disesuaikan dengan 
Mengapa Kedisiplinan Karyawan Lebih Penting Dibandingkan Kepemimpinan Untuk Meningkatkan Kinerja? kebutuhan dari konsumen, seperti ketika konsumen membutuhkan pelayanan untuk mengganti service mesin, maka konsumen akan diarahkan kepada mekanik yang memiliki keahlian dibidang service mesin. Disini juga berperan sebuah sikap dari mekanik serta kepala bengkel. Terlebih dari itu, kemampuan adaptasi individu mekanik dan kepala bengkel antara satu dan lainnya berbeda, di satu sisi pihak manajemen terkesan tidak terlalu peduli dengan situasi dan kondisi ini, dimana menunjukkan bahwa pihak manajemen juga kurang melakukan komunikasi yang baik.

\section{KESIMPULAN}

Penelitian ini memiliki kesimpulan yaitu kepemimpinan kepala mekanik dan kedisiplinan mekanik memang memiliki pengaruh yang signifikan terhadap kinerja mekanik di bengkel bunul malang. Hal ini menjadi tanda bahwa hubungan timbal balik antara kepala bengkel dan mekanik yang baik akan mampu menciptakan kinerja yang diharapkan. Khusus untuk bengkel bunul, kedisiplinan memiliki prioritas untuk ditingkatkan karena awal dari sebuah kedisiplinan mekanik berawal dari kenyamanan bekerja karena kesesuaian karakter antara mekanik dan kepala mekanik. Jika memang terjadi tindakan kurang tegas kepala bengkel terhadap mekanik, sejatinya hanya sebagian dari bentuk toleransi yang diberikan kepala bengkel kepada mekanik, dimana hal ini jangan sampai di salah artikan oleh pihak manajemen.

Terlepas dari itu, mekanik sesungguhnya sudah memahami betul tanggung jawab yang diemban ketika memberikan pelayanan kepada konsumen, sehingga yang menjadi prioritas untuk meningkatkan kinerja mekanik di bengkel bunul adalah tidak melakukan rotasi kepala bengkel dalam periode singkat, serta pemberian toleransi terhadap mekanik bukanlah bentuk tindakan kurang tegas yang harus dihentikan namun lebih kepada memanusiakan mekanik sehingga mekanik merasa bahwa bekerja di bengkel bunul tidak dalam perasaan yang tertekan akan tetapi senang. Permasalahan yang terjadi sebenarnya mengindikasikan adanya kesalahpahaman antara pihak manajemen, kepala bengkel dan mekanik dalam menyikapi sebuah tindakan.

Saran bagi peneliti selanjutnya adalah bisa menggunakan variabel 
Mengapa Kedisiplinan Karyawan Lebih Penting Dibandingkan Kepemimpinan Untuk Meningkatkan Kinerja? komunikasi, sikap, komitmen dan kepuasan kerja sebagai pelengkap untuk penelitian ini. Hal ini karena komunikasi, sikap, komitmen dan kepuasan merupakan bagian yang juga tidak terpisahkan dari sebuah hasil kerja atau kinerja karyawan, dalam hal ini adalah mekanik. Kepala bengkel juga perlu menjadi role model bagi setiap mekanik, baik dari segi keterampilan, sikap maupun memberikan contoh komitmen yang baik. Bentuk-bentuk apresiasi yang kemudian bisa digunakan untuk melakukan modifikasi perilaku oleh kepala bengkel terhadap mekanik yakni dengan memberikan reward yang sesuai. Terutama hal-hal yang terkait dengan komunikasi karena pekerjaan yang terselesaikan dengan baik selalu berawal dari komunikasi yang baik sehingga mampu membentuk sikap, komitmen hingga kepuasan bekerja.

\section{Kesimpulan}

Alexandri, M. B., Pragiwani, M., \& Yuswardi, Y. (2019). The Effect Of Competence And Discipline Of Work On Motivation And Its Impact On Performance of Forensic Checkers At Puslabfor Bareskrim Indonesia National Police (Polri). Academy of Strategic Management Journal, 18(4), 1-13.

Anggreni, P. (2017). Determinasi Motivasi Berprestasi Terhadap KInerja Karyawan Pada Bengkel Autotama Mobil Motor di Karangasem. Forum Manajemen STIMI Handayani Denpasar, 14(2), 78-91.

Aprizal, A., Kurniaty, K., \& Hasriani, H. (2020). Pengaruh Kedisiplinan Terhadap Kinerja Karyawan Pada PT Telkomsel Area IV Pamasuka Kota Makassar | eJournal Ekonomi Bisnis dan Akuntansi. Ekonomi Bisnis Dan Akuntansi, 7(2), 131-135.

Asrar-ul-Haq, M., \& Kuchinke, K. P. (2016). Impact of leadership styles on employees' attitude towards their leader and performance: Empirical evidence from Pakistani banks. Future Business Journal, 2(1), 54-64. https://doi.org/10.1016/j.fbj.2016.05.002

Bagus, I., Surya, K., \& Putra, D. (2015). Pengaruh lingkungan kerja fisik dan stres kerja terhadap kinerja pegawai di UPT. Pengujian kendaraan bermotor dinas perhubungan kota denpasar. E-Jurnal Manajemen Unud, 4(9), 24912506.

Bana, A. (2016). Pengaruh Kepemimpinan Transformasional dan Lingkungan Kerja Fisik terhadap Kinerja Pegawai dengan Motivasi Kerja sebagai Variabel Pemediasi. Jurnal Bisnis Dan Manajemen, 3(1), 1-16.

Christin, J., \& Mukzam, M. D. (2017). Pengaruh Motivasi Internal dan Eksternal terhadap Kinerja Karyawan (Studi Kasus Pada Karyawan PT. Indomarco Prismatama Distribution Centre Bogor). Jurnal Administrasi Bisnis, 50(5), 108-112.

Fatchurozi, F., Sunaryo, H., \& Wahono, B. (2019). Pengaruh Locus of Control, Gaya Kepemimpinan dan Komitmen Organisasi Pada Kinerja Karyawan 
Mengapa Kedisiplinan Karyawan Lebih Penting Dibandingkan Kepemimpinan Untuk Meningkatkan Kinerja? Bank Indonesia Malang. Jurnal Ilmiah Riset Manajemen, 8(03), 16-27.

Hakim, A. F. (2018). Pengaruh Kepemimpinan dan Lingkungan Kerja Fisik terhadap Kinerja Karyawan dengan Kepuasan Kerja sebagai Variabel Intervening (Studi Kasus pada Banjarmasin Post Group). Jurnal Administrasi Bisnis (JAB), 62(2), 131-140.

Indrayani, R., Pujiati, R. S., \& Rusdianto, A. A. (2019). Faktor Keterpaparan Benzena Pada Mekanik di Bengkel Sepeda Motor. IKESMA, 15(1), 1-8. https://doi.org/10.19184/ikesma.v15i1.14417

Kenwa, M. M. L., Wiranadha, I. M., \& Asthuta, A. R. (2019). Hubungan Intensitas Kebisingan Dengan Tingkat Stres Kerja Pada Pekerja Bengkel Motor dan Dealer Dwijati Motor Denpasar. E-Jurnal Medika Udayana, 8(5). https://ojs.unud.ac.id/index.php/eum/article/view/51670

Mataram, A. S., \& Handriyono, H. (2018). Pengaruh Kualitas Kehidupan Kerja dan Kepuasan Kerja Terhadap Kinerja Karyawan Melalui Komitmen Organisasi Pada Bengkel Resmi Sepeda Motor Honda di Kecamatan Sumbersari Kabupaten Jember. BISMA: Jurnal Bisnis Dan Manajemen, 12(1), 81-91. https://doi.org/10.19184/bisma.v12i1.7605

Mintarsih, M., \& Anisya, Y. (2019). Pengaruh Gaya Kepemimpinan Terhadap Kinerja Karyawan Bagian Pengadaan Barang Pada PT. Indomarco Prismatama (Indomaret Group). JMBA: Jurnal Manajemen Dan Bisnis, 5(1), 1-11.

Nidawati, N. I. (2019). Analisis Motivasi dan Kemampuan Kerja Terhadap Kepuasan Kerja dan Kinerja Karyawan Pada Bengkel UD. Rio Motor Angsana Kabupaten Tanah Bumbu Borneo Selatan. Jurnal Ilmiah Ekonomi Bisnis, 5(2), 290-300. https://doi.org/10.35972/jieb.v5i2.279

Nugraha, R., Harsono, A., \& Adianto, H. (2014). Usulan Peningkatan Kualitas Pelayanan Jasa pada Bengkel "X" Berdasarkan Hasil Matrix ImportancePerformance Analysis* (Studi Kasus di Bengkel AHASS PD. Sumber Motor Karawang). Reka Integra, 1(3), 11.

Pawirosumarto, S., Sarjana, P. K., \& Muchtar, M. (2017). Factors affecting employee performance of PT.Kiyokuni Indonesia. International Journal of Law and Management, 59(4), 602-614. https://doi.org/10.1108/IJLMA-032016-0031

Prabowo, T. S., Noermijati, N., \& Irawanto, D. W. (2018). The influence of transformational leadership and work motivation on employee performance mediated by job satisfaction. JAM: Jurnal Aplikasi Manajemen, 16(1), 171-178.

Purba, A. R., Hutagalung, N. Y., Putri, E., \& Nazmi, H. (2020). Pengaruh Kepemimpinan, Motivasi dan Kedisiplinan Terhadap Kinerja Karyawan Pada PT. Santika Premiere Dyandra. Jurnal Ilmu Manajemen METHONOMIX, 3(1), 11-18. https://doi.org/10.46880/31

Ramliana, R., Ansir, A., \& Sinarwaty, S. (2017). Pengaruh Perilaku Kepemimpinan dan Kedisiplinan Terhadap Kinerja Pegawai. Jurnal Manajemen, Bisnis Dan Organisasi (JUMBO), 1(3), Article 3. https://doi.org/10.33772/jumbo.v1i3.8000

Rita, M., Randa Payangan, O., Rante, Y., Tuhumena, R., \& Erari, A. (2018). 
Mengapa Kedisiplinan Karyawan Lebih Penting Dibandingkan Kepemimpinan Untuk Meningkatkan Kinerja?

Moderating effect of organizational citizenship behavior on the effect of organizational commitment, transformational leadership and work motivation on employee performance. International Journal of Law and Management, 60(4), 953-964. https://doi.org/10.1108/IJLMA-03-20170026

Rizal, A. S. (2019). Pengaruh Motivasi Kerja dan Kedisiplinan Terhadap Kinerja Guru SMP. Jurnal Ulul Albab, 23(1), 15-22. https://doi.org/10.31764/jua.v23i1.658

Schleu, J. E., \& Hüffmeier, J. (2020). Simply the best? A systematic literature review on the predictive validity of employee performance for leader performance. Human Resource Management Review, 100777. https://doi.org/10.1016/j.hrmr.2020.100777

Soelton, M. (2018). How Culture, Training Standard and Discipline on the Employee Performance Affect Hotel Management. EUROPEAN RESEARCH STUDIES JOURNAL, XXI(Issue 4), 378-385. https://doi.org/10.35808/ersj/1128

Syukri, M., \& Heryanto, H. (2019). The Influence Of Leadership Style, And Organizational Commitment, On Employee Discipline And Also Its Impact On Employee Performance Of The Dharmasraya District Community And Village Empowerment Office. Archives of Business Research, 7(7), 102-111.

Winarto, C. A., \& Laela, S. (2017). Pengaruh Pelatihan dan DIsiplin Kerja Terhadap Kinerja Karyawan Bengkel. Jurnal Pengembangan Wiraswasta, 18(3), 261-270. https://doi.org/10.33370/jpw.v18i3.56

Yogatama, A. N. (2019). Kecerdasan Spiritual dalam Prestasi Kerja Karyawan. An-Nisbah: Jurnal Ekonomi Syariah, 5(2), 128-146. https://doi.org/10.13140/RG.2.2.32679.39845

Yogatama, A. N., \& Mudhawati, W. A. (2020). Bagaimana Meningkatkan Kinerja Karyawan Secara Efektif? (Studi Pada Driver Perusahaan Batu Bara Job Site Bengalon). JMK (Jurnal Manajemen Dan Kewirausahaan), 5(1), 40-51. https://doi.org/10.32503/jmk.v5i1.733

Yogatama, A. N., \& Susanti, D. R. D. (2020). Why Employee Job Satisfaction is More Important than Leadership ?: A Case Study at SMEs. International Journal of Advances in Social and Economics, 2(1), Article 1. https://doi.org/10.33122/ijase.v2i1.80 